Proceedings of International Mathematical Sciences

ISSN:2717-6355, URL: HTTPS://DERGIPARK.ORG.TR/TR/PUB/PIMS

Volume III Issue 1 (2021), Pages 10-24.

DOI: HTTPS://DOI.ORG/10.47086/PIMS.952438

\title{
COLD WEATHER TEAMS IN THE NATIONAL FOOTBALL LEAGUE AND HOME-FIELD ADVANTAGE
}

\author{
BRANDON JOLY* AND MEHMET DIK** \\ *BELOIT, WISCONSIN, USA. \\ **BELOIT, WISCONSIN, USA.
}

\begin{abstract}
The National Football League (NFL) has long had this idea of home-field advantage when teams play at home where they win more of their games. However, home games entail many things such as home fan attendance and weather. In considering the mean winning percentage of home games played during the winter months of December, January, and February by Cold Weather Teams, and the mean winning percentage of all home games played and all December, January, and February home games played, the null hypothesis would be that there is no difference in the means. By rejecting the null hypothesis, it would lead to the conclusion that cold weather plays a factor in determining NFL games. This hypothesis testing is important because if teams in "colder weather climates" gain a significant advantage during the colder months of December, January, and February, the impacts of playing in an open grass stadium during these months will have a greater impact on the playoffs and draft, which is decided based on final NFL standings. The finding is that Cold Weather Teams have a significant advantage when compared to the other data found, which suggests that cold weather tends to impact NFL games more than expected.
\end{abstract}

\section{INTRODUCTION}

Before the start of the 2021 league year and since the 2002 season, the NFL has been composed of 32 teams, each team playing 16 games, 8 of which are considered home games [1]. From 2002-2019, the NFL would play a total of 266 games that included a home team, which included playoff games, but excluded the Super Bowl which is played on a neutral field; however, in 2020, the NFL expanded the playoff field by one team in the American Football Conference (AFC) and National Football Conference (NFC) to create 268 games that included a home team [2]. However, the 2020 NFL season is full of oddities, including changes to the schedule of 11 teams due to the Covid-19 pandemic [3], resulting in the Denver Broncos without a starting quarterback (QB) play a game [4], and it is also the first time the host

2020 Mathematics Subject Classification. 62D05.

Key words and phrases. NFL home-field advantage; hypothesis testing; paired differences test; cold weather teams.

(C) 2021 Proceedings of International Mathematical Sciences.

Submitted on 14.06.2021, Accepted on 28.06.2021.

Communicated by Ibrahim Canak. 
city of Super Bowl game was the home stadium of a team that participated, which brings the number of home games of the first team to 269 [5]. In completion, this research project is trying to reject the null hypothesis that there is not a significant advantage for the Cold Weather Teams, during the months of December, January, and February.

\section{Method And Materials}

The research project defines home games as games that are played at a team's home-field or was voluntarily played at a neutral site in agreement with the NFL that the game would count as a home game for that team in order to include games played in London, Canada, and other places. The definition used to determine "cold weather games" was if the game was played in December, January, or February of any given league season. In reference to "cold weather teams" this is for teams that play in an outdoor environment (not a dome) above the $39^{\circ} \mathrm{N}$ latitude line. These teams include the Chicago Bears (Memorial Stadium used in 2002 at $40.099365234^{\circ} \mathrm{N}$ [6], Soldier Field used from 2003-Present at $41.8625332^{\circ} \mathrm{N}$ ) [7], Green Bay Packers (Lambeau Field used from 1957-Present at $44.501389^{\circ} \mathrm{N}$ ) [8], Kansas City Chiefs (Arrowhead Stadium used from 1972-Present at $39.048889^{\circ} \mathrm{N}$ ) [9], Buffalo Bills (Bills Stadium used from 1973-Present at $42.774^{\circ} \mathrm{N}$ [10] and "Toronto Series" from 2008-2011 at the Rogers Centre, Toronto Canada [11] at 43.641438 N)[12], Cleveland Browns (FirstEnergy Stadium used from 1999-Present at $41.506111^{\circ} \mathrm{N}$ ) [13], Cincinnati Bengals (Paul Brown Stadium used from 2000Present at $39.095^{\circ} \mathrm{N}$ ) [14], Denver Broncos (Empower Field at Mile High used from 2001-Present at $39.743952^{\circ} \mathrm{N}$ )[15], New England Patriots (Gillette Stadium used from 2002-Present at $42.091^{\circ} \mathrm{N}$ )[16], Pittsburgh Steelers (Heinz Field used from 2001-Present at $40.446667^{\circ} \mathrm{N}$ )[17], Philadelphia Eagles (Veterans Stadium used from 1971-2002 at 39.906667 ${ }^{\circ}$ [18], Lincoln Financial Field used from 2003-Present at $39.900833^{\circ} \mathrm{N}$ )[19], Seattle Seahawks (Lumen Field used from 2002-Present at $47.5952^{\circ} \mathrm{N}$ ) [20], Baltimore Ravens (M\&T Bank Stadium used from 1998-Present at $39.278056^{\circ} \mathrm{N}$ )[21], New York Jets and Giants (Giants Stadium used from 1984-2009 at $40.812222^{\circ} \mathrm{N}$ [22], MetLife Stadium used from 2010-Present at $40.813528^{\circ} \mathrm{N}$ ) [23], and Minnesota Vikings (TCF Bank Stadium [64] used from 2014-2015 at 44.976 ${ }^{\circ}$ N) [24]. The research only takes into account home games from the 2002 season and onwards because that is when the Houston Texans became the 32nd team in the NFL $[25]$.

\section{RESULTS}

Between the years 2002-2020, there were 5057 games in this time period. The overall record of all teams was 5046-5046-22 which gives you an overall winning percentage of $50 \%$ or 0.50 . This will allow this study to assume the odds of winning or losing a football game in the NFL is $50 / 50$ probability and is random which is defined by "events that cannot be predicted with certainty, but the relative frequency with which they occur in a long series of trials is often remarkably stable," [26]. The table and graph below shows this phenomenon is associated with NFL teams and their winning percentage, home-field winning percentage, and cold weather winning percentage from 2002-2019 and 2002-2020. *Winning percentage was calculated by taking (wins $+\left(\right.$ ties*0.5) $\left.^{*}\right) /($ total number of games).* 
Table 1: NFL Teams Winning Percentages Table.

\begin{tabular}{|c|c|c|c|c|c|c|}
\hline \multicolumn{7}{|c|}{ NFL Winning Percentages [27] } \\
\hline Team & $\begin{array}{l}2002- \\
2019\end{array}$ & $\begin{array}{l}2002- \\
2020\end{array}$ & \begin{tabular}{|l} 
Home- \\
field \\
$2002-$ \\
2019 \\
\end{tabular} & $\begin{array}{l}\text { Home- } \\
\text { field } \\
2002- \\
2020\end{array}$ & $\begin{array}{l}\text { Cold } \\
\text { Weather } \\
2002- \\
2019 \\
\end{array}$ & $\begin{array}{l}\text { Cold } \\
\text { Weather } \\
2002- \\
2020 \\
\end{array}$ \\
\hline $\begin{array}{l}\text { Atlanta Fal- } \\
\text { cons } \quad \text { (Atl) } \\
{[28]}\end{array}$ & 0.528 & 0.514 & 0.587 & 0.570 & 0.587 & 0.562 \\
\hline $\begin{array}{l}\text { Arizona Car- } \\
\text { dinals (Ari) } \\
{[29]}\end{array}$ & 0.448 & 0.450 & 0.568 & 0.564 & 0.640 & 0.623 \\
\hline $\begin{array}{l}\text { Baltimore } \\
\text { Ravens (Bal) } \\
{[30]}\end{array}$ & 0.580 & 0.585 & 0.720 & 0.715 & 0.673 & 0.691 \\
\hline $\begin{array}{l}\text { Buffalo Bills } \\
\text { (Buf) [31] }\end{array}$ & 0.434 & 0.456 & 0.521 & 0.545 & 0.489 & 0.531 \\
\hline $\begin{array}{l}\text { Carolina } \\
\text { Panthers } \\
\text { (Car) [32] }\end{array}$ & 0.522 & 0.511 & 0.567 & 0.551 & 0.660 & 0.633 \\
\hline $\begin{array}{l}\text { Cincinnati } \\
\text { Bengals } \\
\text { (Cin) [33] }\end{array}$ & 0.463 & 0.453 & 0.537 & 0.529 & 0.553 & 0.540 \\
\hline $\begin{array}{l}\text { Chicago } \\
\text { Bears (Chi) } \\
{[34]}\end{array}$ & 0.481 & 0.481 & 0.547 & 0.538 & 0.500 & 0.491 \\
\hline $\begin{array}{l}\text { Cleveland } \\
\text { Browns } \\
\text { (Cle) }[35]\end{array}$ & 0.310 & 0.331 & 0.378 & 0.398 & 0.351 & 0.364 \\
\hline $\begin{array}{ll}\text { Dallas } & \text { Cow- } \\
\text { boys } & \text { (Dal) } \\
{[36]} & \end{array}$ & 0.540 & 0.531 & 0.584 & 0.580 & 0.462 & 0.488 \\
\hline $\begin{array}{l}\text { Denver } \\
\text { Broncos } \\
\text { (Den) [37] }\end{array}$ & 0.563 & 0.550 & 0.647 & 0.627 & 0.66 & 0.635 \\
\hline $\begin{array}{l}\text { Detroit } \begin{array}{r}\mathrm{Li}- \\
\text { ons } \\
{[38]}\end{array} \quad\end{array}$ & 0.356 & 0.353 & 0.444 & 0.428 & 0.333 & 0.310 \\
\hline $\begin{array}{l}\text { Houston } \\
\text { Texans } \\
\text { (Hou) [39] }\end{array}$ & 0.453 & 0.443 & 0.540 & 0.525 & 0.542 & 0.510 \\
\hline $\begin{array}{l}\text { Green Bay } \\
\text { Packers } \\
\text { (GB) }[40]\end{array}$ & 0.606 & 0.615 & 0.697 & 0.703 & 0.745 & 0.750 \\
\hline $\begin{array}{l}\text { Indianapolis } \\
\text { Colts (Ind) } \\
{[41]}\end{array}$ & 0.620 & 0.621 & 0.697 & 0.699 & 0.759 & 0.768 \\
\hline
\end{tabular}




\begin{tabular}{|c|c|c|c|c|c|c|}
\hline \multicolumn{7}{|c|}{ Continuation of Table 6} \\
\hline Team & $\begin{array}{l}2002- \\
2019\end{array}$ & $\begin{array}{l}2002- \\
2020\end{array}$ & $\begin{array}{l}\text { Home- } \\
\text { field } \\
2002- \\
2019\end{array}$ & $\begin{array}{l}\text { Home- } \\
\text { field } \\
2002- \\
2020\end{array}$ & $\begin{array}{l}\text { Cold } \\
\text { Weather } \\
2002- \\
2019\end{array}$ & $\begin{array}{l}\text { Cold } \\
\text { Weather } \\
2002- \\
2020\end{array}$ \\
\hline $\begin{array}{l}\text { Jacksonville } \\
\text { Jaguars } \\
\text { (Jax) [42] }\end{array}$ & 0.398 & 0.381 & 0.483 & 0.464 & 0.500 & 0.479 \\
\hline $\begin{array}{l}\text { Kansas City } \\
\text { Chiefs (KC) } \\
{[43]}\end{array}$ & 0.525 & 0.544 & 0.592 & 0.605 & 0.630 & 0.644 \\
\hline $\begin{array}{l}\text { Las Vegas } \\
\text { Raiders } \\
\text { (LVR) [44] }\end{array}$ & 0.360 & 0.367 & 0.432 & 0.422 & 0.422 & 0.396 \\
\hline $\begin{array}{l}\text { Los Angeles } \\
\text { Chargers } \\
\text { (LAC) [45] }\end{array}$ & 0.537 & 0.532 & 0.591 & 0.586 & 0.588 & 0.593 \\
\hline $\begin{array}{l}\text { Los Angeles } \\
\text { Rams (LAR) } \\
{[46]}\end{array}$ & 0.419 & 0.430 & 0.476 & 0.490 & 0.422 & 0.447 \\
\hline $\begin{array}{l}\text { Miami Dol- } \\
\text { phins (Mia) } \\
{[47]}\end{array}$ & 0.438 & 0.448 & 0.503 & 0.510 & 0.551 & 0.558 \\
\hline $\begin{array}{l}\text { Minnesota } \\
\text { Vikings } \\
\text { (Min) [48] }\end{array}$ & 0.515 & 0.511 & 0.649 & 0.635 & 0.592 & 0.588 \\
\hline $\begin{array}{l}\text { New Eng- } \\
\text { land Patriots } \\
\text { (NE) [49] }\end{array}$ & 0.761 & 0.746 & 0.838 & 0.829 & 0.838 & 0.829 \\
\hline $\begin{array}{l}\text { New York } \\
\text { Giants } \\
\text { (NYG) }[50]\end{array}$ & 0.488 & 0.483 & 0.490 & 0.484 & 0.404 & 0.400 \\
\hline $\begin{array}{lr}\text { New } & \text { York } \\
\text { Jets } & \text { (NYJ) } \\
{[51]} & \end{array}$ & 0.452 & 0.435 & 0.531 & 0.510 & 0.581 & 0.578 \\
\hline $\begin{array}{l}\text { Philadelphia } \\
\text { Eagles (Phi) } \\
{[52]}\end{array}$ & 0.580 & 0.565 & 0.609 & 0.601 & 0.600 & 0.596 \\
\hline $\begin{array}{l}\text { Pittsburgh } \\
\text { Steelers } \\
\text { (Pit) [53] }\end{array}$ & 0.637 & 0.640 & 0.706 & 0.710 & 0.724 & 0.710 \\
\hline $\begin{array}{l}\text { San Fran- } \\
\text { cisco } 49 \mathrm{ers} \\
\text { (SF) }[54]\end{array}$ & 0.460 & 0.456 & 0.557 & 0.535 & 0.630 & 0.592 \\
\hline $\begin{array}{l}\text { Seattle Sea- } \\
\text { hawks (Sea) } \\
{[55]}\end{array}$ & 0.578 & 0.585 & 0.703 & 0.707 & 0.702 & 0.689 \\
\hline
\end{tabular}




\begin{tabular}{|l||l|l|l|l|l|l|}
\hline \multicolumn{9}{|c|}{ Continuation of Table 6} \\
\hline Team & $\begin{array}{l}2002- \\
2019\end{array}$ & $\begin{array}{l}2002- \\
2020\end{array}$ & $\begin{array}{l}\text { Home- } \\
\text { field } \\
2002- \\
2019\end{array}$ & $\begin{array}{l}\text { Home- } \\
\text { field } \\
2002- \\
2020\end{array}$ & $\begin{array}{l}\text { Cold } \\
\text { Weather } \\
2002- \\
2019\end{array}$ & $\begin{array}{l}\text { Cold } \\
\text { Weather } \\
2002- \\
2020\end{array}$ \\
\hline $\begin{array}{l}\text { Tampa Bay } \\
\text { Buccaneers } \\
\text { (TB) [56] } \\
\begin{array}{l}\text { Tennessee } \\
\text { Titans (Ten) }\end{array}\end{array}$ & 0.416 & 0.438 & 0.449 & 0.462 & 0.333 & 0.375 \\
$\begin{array}{l}\text { [57] } \\
\text { Washington }\end{array}$ & 0.485 & 0.494 & 0.534 & 0.535 & 0.571 & 0.558 \\
$\begin{array}{l}\text { Football } \\
\text { Team } \\
\text { (WFT) }\end{array}$ & 0.401 & 0.402 & 0.445 & 0.439 & 0.311 & 0.292 \\
$\begin{array}{l}{[58]} \\
\text { New Orleans } \\
\text { Saints (NO) } \\
{[59]}\end{array}$ & 0.574 & 0.583 & 0.612 & 0.617 & 0.509 & 0.517 \\
\hline \multicolumn{7}{|l|}{ End of Table-*all decimals were rounded to the nearest thousandth* } \\
\hline
\end{tabular}

NFL Winning Percentages

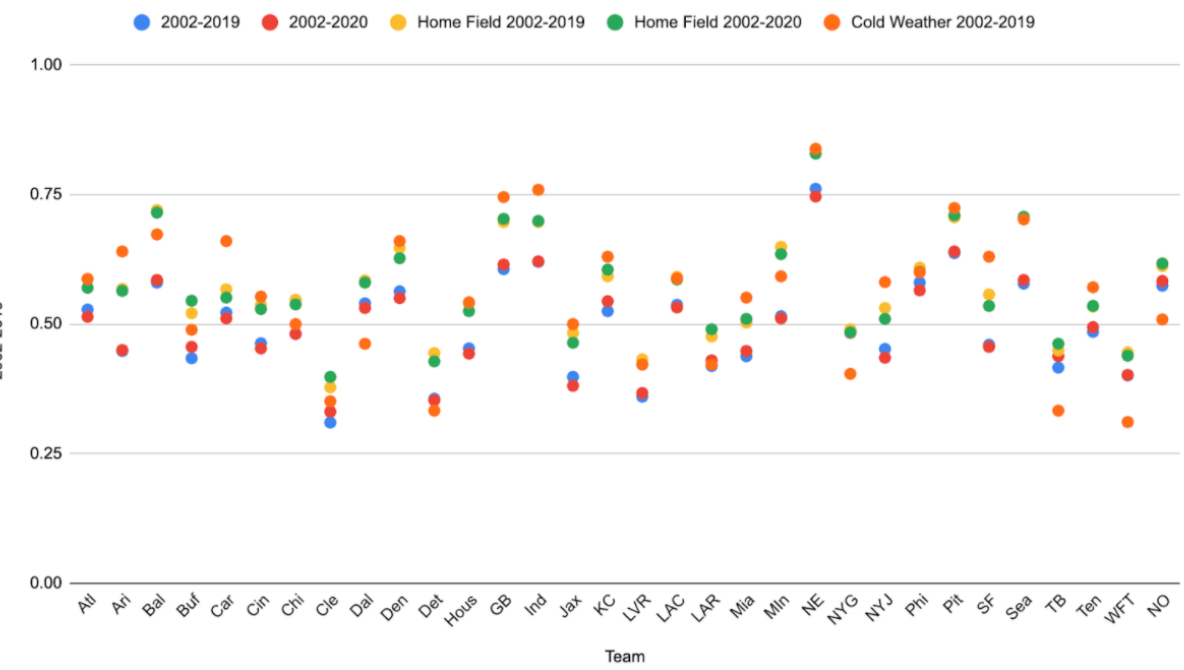

FiguRE 1. Graph: Scatterplot showing teams winning percentages.

This data was used and then compiled on a season by season basis to construct the following table and graph. 
Table 2: Entire NFL Winning Percentage Season By Season Table.

\begin{tabular}{|l||l|l|}
\hline \multicolumn{3}{|c|}{ Entire NFL Winning Percentage Season By Season } \\
\hline Year & Home Games & $\begin{array}{l}\text { Cold Weather Team } \\
\text { Games at Home During } \\
\text { December, January, and } \\
\text { February }\end{array}$ \\
\hline 2002 & 0.5883458647 & 0.6829268293 \\
2003 & 0.6127819549 & 0.7105263158 \\
2004 & 0.5676691729 & 0.625 \\
2005 & 0.5827067669 & 0.6363636364 \\
2006 & 0.5413533835 & 0.575 \\
2007 & 0.5714285714 & 0.6315789474 \\
2008 & 0.5695488722 & 0.6129032258 \\
2009 & 0.5751879699 & 0.5526315789 \\
2010 & 0.5526315789 & 0.5909090909 \\
2011 & 0.5751879699 & 0.619047619 \\
2012 & 0.5733082707 & 0.5853658537 \\
2013 & 0.5996240602 & 0.6097560976 \\
2014 & 0.5770676692 & 0.6216216216 \\
2015 & 0.5413533835 & 0.5652173913 \\
2016 & 0.5864661654 & 0.6888888889 \\
2017 & 0.5714285714 & 0.5609756098 \\
2018 & 0.5977443609 & 0.6341463415 \\
2019 & 0.5206766917 & 0.6341463415 \\
2020 & 0.5 & 0.5909090909 \\
\hline \multicolumn{2}{|c|}{ End of Table } \\
\hline \hline
\end{tabular}

The overall winning percentages for home games including the 2020 NFL season is 0.5686177576 and without the 2020 season is 0.5724728488. Similarly, the overall winning percentages for Cold Weather Teams including the 2020 season is 0.617076326 and without 0.6186556927 . These numbers will vary from the mean due to a different number of games being played every season. For this set of data we found the mean $(\bar{x})$, population standard deviation $(\sigma)$, and sample standard deviation (s) for home games, Cold Weather Team games at home during December, January, and February, and all team games at home during December, January, and February for with data that included and was without the 2020 NFL season.

\begin{tabular}{|l||l|l|l|}
\hline \multicolumn{3}{|c|}{ Table of Standard Deviations and Arithmetic Means with the 2020 Season } \\
\hline $\begin{array}{l}\text { Mathematical } \\
\text { Method }\end{array}$ & Home games & $\begin{array}{l}\text { Cold } \\
\text { Team Geather } \\
\text { Home ames at } \\
\text { December, January }\end{array}$ & $\begin{array}{l}\text { All Team Games at } \\
\text { Home During De- } \\
\text { cember, January, } \\
\text { and February }\end{array}$ \\
\hline $\begin{array}{l}\bar{x} \text { arithmetic mean } \\
\text { s sample standard } \\
\text { deviation } \\
\begin{array}{l}\sigma \text { population stan- } \\
\text { dard deviation }\end{array}\end{array}$ & 0.5686584883 & 0.6172586568 & 0.566979456 \\
0.02750025926 & 0.04325904819 & 0.05386899073 \\
\hline
\end{tabular}




\section{NFL Home Winning Percentage for Cold Weather and All Home Games}

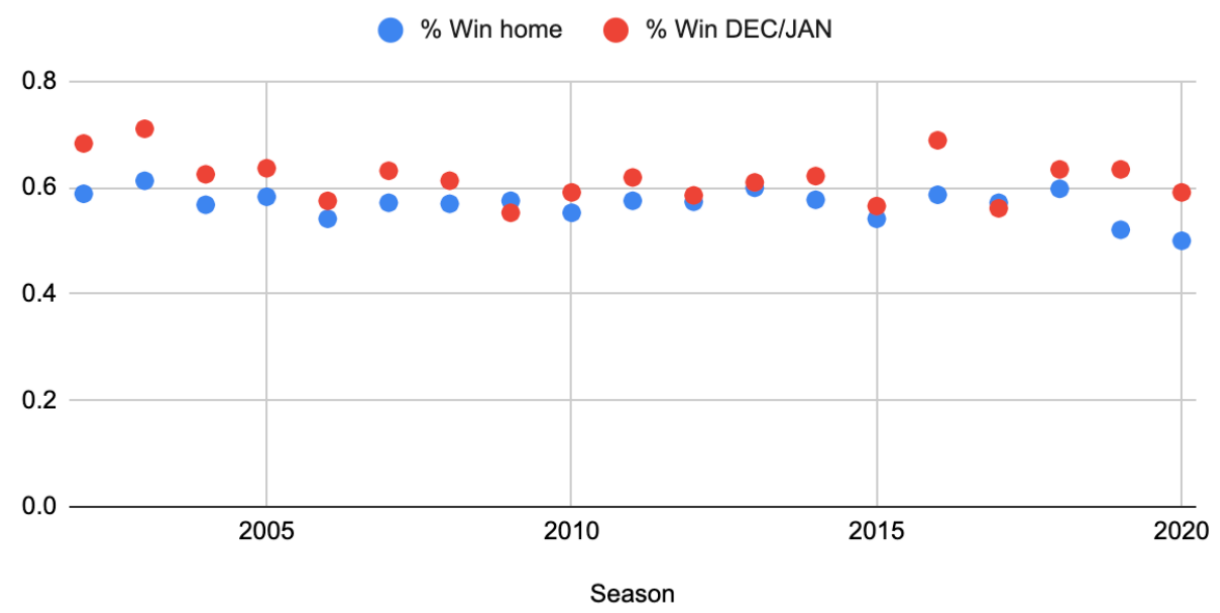

Figure 2. Graph 2: This is the NFL winning percentages for all home teams and cold weather teams including the 2020 season.

\begin{tabular}{|l||l|lr|l|}
\hline \multicolumn{3}{|c|}{ Table of Standard Deviations and Arithmetic Means without the 2020 Season } \\
\hline $\begin{array}{l}\text { Mathematical } \\
\text { Method }\end{array}$ & Home games & $\begin{array}{l}\text { Cold Weather } \\
\text { Team Games at } \\
\text { Homer During } \\
\text { December, January }\end{array}$ & $\begin{array}{l}\text { All Team Games at } \\
\text { Home During De- } \\
\text { cember, January, } \\
\text { and February }\end{array}$ \\
\hline $\begin{array}{l}\bar{x} \text { arithmetic mean } \\
\text { s sample standard } \\
\text { deviation } \\
\begin{array}{l}\sigma \text { population stan- } \\
\text { dard deviation }\end{array}\end{array}$ & 0.5724728488 & 0.6187225216 & 0.5715965942 \\
0.0225400042 & 0.04402629073 & 0.0514169134 \\
\hline
\end{tabular}

The formula used for the arithmetic mean $(\bar{x})$ was $\bar{x}=\frac{1}{n} \sum_{i=1}^{n} x_{i}$, where $\mathrm{n}=$ number of values and $x_{i}=$ data set values.

The formula used for sample standard deviation (s) was $\mathrm{s}=\sqrt{\frac{\sum_{i=1}^{N}\left(x_{i}-\bar{x}\right)^{2}}{N-1}}$ where $\mathrm{N}=$ the number of observations, $x_{i}=$ data set values, and $(\bar{x})$ is the arithmetic mean.

The formula used for population standard deviation $(\sigma)$ was $\sigma=\sqrt{\frac{\sum_{i=1}^{N}\left(x_{i}-\mu\right)^{2}}{N-1}}$ $\mathrm{N}=$ the number of observations, $x_{i}=$ data set values, and $(\mu)$ is the population mean.

In this case, $\mu=\bar{x}$ because the study has a set number of data points. For the purpose of this study, the study will run 4 hypotheses tests because the 2020 NFL season was considered an outlier. An outlier is "data values that are very different from other measurements in the data set." [60] The study assumes based on Las Vegas and the gambling markets assumption in making their lines and odds that home-field advantage exists within the NFL and is shown through home teams having a winning percentage of 0.5686177576 and 0.5724728488 (when you don't include the 2020 NFL season) [61]. The tests run will be a right-tailed dependent samples paired differences test because the samples can be deemed to be dependent 
on the other since a home game of cold weather teams during December, January, and February will also be included in the sample of all team games at home during December, January, and February and all home games. Thus, this clearly passes the definition of dependent samples being "each data value in one sample can be paired with a corresponding data value in the other sample," [60]. Using the test outlines and tables provided by Brasse and Brasse (2009), the tests were done as follows.

3.1. Test 1: Cold Weather Teams Games at Home During December, January, and February, and All Team Games at Home During December, January, and February (including the 2020 NFL Season). .

$H_{0}: \mu_{d}=0, H_{1}: \mu_{d}>0, \alpha=0.01$

The study begins by pairing the seasons together as a pair. For instance, 2002 Cold Weather Team Winning Percentage with All Team Home Games During December, January, and February Winning Percentage which leaves the following table.

Table 3: Paired Differences Table for Test 1.

\begin{tabular}{|l||l||l|l|}
\hline \multicolumn{5}{|c|}{ Paired Differences Table } \\
\hline Season & $\begin{array}{l}\text { Cold Weather } \\
\text { Team Games at } \\
\text { Home During De- } \\
\text { cember, January, } \\
\text { and February (B) }\end{array}$ & $\begin{array}{l}\text { All Team Games at } \\
\text { Homeduring De- } \\
\text { cember, January, } \\
\text { and February (A) }\end{array}$ & \\
\hline 2002 & 0.6829268293 & 0.6136363636 & 0.06929046563 \\
2003 & 0.7105263158 & 0.6623376623 & 0.04818865345 \\
2004 & 0.625 & 0.5888888889 & 0.03611111111 \\
2005 & 0.6363636364 & 0.5444444444 & 0.09191919192 \\
2006 & 0.575 & 0.4494382022 & 0.1255617978 \\
2007 & 0.6315789474 & 0.606741573 & 0.02483737433 \\
2008 & 0.6129032258 & 0.64 & -0.02709677419 \\
2009 & 0.5526315789 & 0.5444444444 & 0.008187134503 \\
2010 & 0.5909090909 & 0.5222222222 & 0.06868686869 \\
2011 & 0.619047619 & 0.5888888889 & 0.03015873016 \\
2012 & 0.5853658537 & 0.5730337079 & 0.01233214579 \\
2013 & 0.6097560976 & 0.5862068966 & 0.02354920101 \\
2014 & 0.6216216216 & 0.5466666667 & 0.07495495495 \\
2015 & 0.5652173913 & 0.5161290323 & 0.04908835905 \\
2016 & 0.6888888889 & 0.6 & 0.08888888889 \\
2017 & 0.5609756098 & 0.6153846154 & -0.05440900563 \\
2018 & 0.6341463415 & 0.5730337079 & 0.0611126336 \\
2019 & 0.6341463415 & 0.5172413793 & 0.1169049622 \\
2020 & 0.5909090909 & 0.4838709677 & 0.1070381232 \\
\hline
\end{tabular}

From the table, the study finds that $\bar{d}=0.05027920086$ and $s_{d}=0.04720562542$. $\mathrm{n}=19$.

$$
\begin{aligned}
& t=\frac{\bar{d}}{\frac{s_{d}}{\sqrt{n}}}=\frac{0.05027920086}{\frac{0.04720566542}{\sqrt{19}}}=4.64241 \\
& \text { d.f. }=\mathrm{n}-1=19-1=18
\end{aligned}
$$


The P-value falls to the right of 3.922 from the "Critical Values for Student's t distribution." $3.922<\mathrm{P}-$ Value for the sample $\mathrm{t}$.

Since the interval containing the P-Value of sample t lies to the right of $\alpha=0.01$, we reject $H_{0}$.

At the $1 \%$ level of significance and even the $0.1 \%$ level of significance, we conclude that the Cold Weather Team Games at Home During December, January have an advantage over All Team Games at Home During December, January, and February which includes the 2020 season.

3.2. Test 2: Cold Weather Teams Games at Home During December, January, and February, and All Team Games at Home During December, January, and February (without the 2020 NFL Season). .

$H_{0}: \mu_{d}=0, H_{1}: \mu_{d}>0, \alpha=0.01$

The study begins by pairing the seasons together as a pair. For instance, 2002 Cold Weather Team Winning Percentage with All Team Home Games During December, January, and February Winning Percentage which leaves the following table.

Table 4: Paired Differences Table for Test 2.

\begin{tabular}{|l||l||l|l|}
\hline \multicolumn{5}{|c|}{ Paired Differences Table } \\
\hline Season & $\begin{array}{l}\text { Cold Weather } \\
\text { Team Games at } \\
\text { Home During De- } \\
\text { cember, January, } \\
\text { and February (B) }\end{array}$ & $\begin{array}{l}\text { All Team Games at } \\
\text { Homering De- } \\
\text { cember, January, } \\
\text { and February (A) }\end{array}$ & \\
\hline 2002 & 0.6829268293 & 0.6136363636 & 0.06929046563 \\
2003 & 0.7105263158 & 0.6623376623 & 0.04818865345 \\
2004 & 0.625 & 0.5888888889 & 0.03611111111 \\
2005 & 0.6363636364 & 0.5444444444 & 0.09191919192 \\
2006 & 0.575 & 0.4494382022 & 0.1255617978 \\
2007 & 0.6315789474 & 0.606741573 & 0.02483737433 \\
2008 & 0.6129032258 & 0.64 & -0.02709677419 \\
2009 & 0.5526315789 & 0.5444444444 & 0.008187134503 \\
2010 & 0.5909090909 & 0.5222222222 & 0.06868686869 \\
2011 & 0.619047619 & 0.5888888889 & 0.03015873016 \\
2012 & 0.5853658537 & 0.5730337079 & 0.01233214579 \\
2013 & 0.6097560976 & 0.5862068966 & 0.02354920101 \\
2014 & 0.6216216216 & 0.5466666667 & 0.07495495495 \\
2015 & 0.5652173913 & 0.5161290323 & 0.04908835905 \\
2016 & 0.6888888889 & 0.6 & 0.08888888889 \\
2017 & 0.5609756098 & 0.6153846154 & -0.05440900563 \\
2018 & 0.6341463415 & 0.5730337079 & 0.0611126336 \\
2019 & 0.6341463415 & 0.5172413793 & 0.1169049622 \\
\hline
\end{tabular}

From the table, the study finds that $\bar{d}=0.0471259274$ and $s_{d}=0.04646955209$. $\mathrm{n}=18$.

$$
\begin{aligned}
& t=\frac{\bar{d}}{\frac{s_{d}}{\sqrt{n}}}=\frac{0.0471259274}{\frac{0.0464695209}{\sqrt{18}}}=4.30345 \\
& \text { d.f. }=\mathrm{n}-1=18-1=17
\end{aligned}
$$


The P-value falls to the right of 3.965 from the "Critical Values for Student's t distribution." $3.965<\mathrm{P}$-Value for the sample t.

Since the interval containing the P-Value of sample t lies to the right of $\alpha=0.01$, we reject $H_{0}$.

At the $1 \%$ level of significance and even the $0.1 \%$ level of significance, we conclude that the Cold Weather Team Games at Home During December, January have an advantage over All Team Games at Home During December, January, and February which does not include the 2020 season.

3.3. Test 3:Cold Weather Teams Games at Home During December, January, and February, and All Home Games (including the 2020 NFL Season). .

$H_{0}: \mu_{d}=0, H_{1}: \mu_{d}>0, \alpha=0.01$

The study begins by pairing the seasons together as a pair. For instance, 2002 Cold Weather Team Winning Percentage with All Team Home Games Winning Percentage which leaves the following table.

Table 5: Paired Differences Table for Test 3.

\begin{tabular}{|l||l||l|l|}
\hline \multicolumn{5}{|c|}{ Paired Differences Table } \\
\hline Season & $\begin{array}{l}\text { Cold Weather } \\
\text { Team Games at } \\
\text { Home During De- } \\
\text { cember, January, } \\
\text { and February (B) }\end{array}$ & All Team Games at & D=B-A \\
\hline 2002 & 0.6829268293 & 0.5883458647 & 0.09458096461 \\
2003 & 0.7105263158 & 0.6127819549 & 0.0977443609 \\
2004 & 0.625 & 0.5676691729 & 0.05733082707 \\
2005 & 0.6363636364 & 0.5827067669 & 0.05365686945 \\
2006 & 0.575 & 0.5413533835 & 0.03364661654 \\
2007 & 0.6315789474 & 0.5714285714 & 0.06015037594 \\
2008 & 0.6129032258 & 0.5695488722 & 0.04335435363 \\
2009 & 0.5526315789 & 0.5751879699 & -0.02255639098 \\
2010 & 0.5909090909 & 0.5526315789 & 0.03827751196 \\
2011 & 0.619047619 & 0.5751879699 & 0.04385964912 \\
2012 & 0.5853658537 & 0.5733082707 & 0.01205758298 \\
2013 & 0.6097560976 & 0.5996240602 & 0.01013203741 \\
2014 & 0.6216216216 & 0.5770676692 & 0.04455395245 \\
2015 & 0.5652173913 & 0.5413533835 & 0.02386400785 \\
2016 & 0.6888888889 & 0.5864661654 & 0.1024227235 \\
2017 & 0.5609756098 & 0.5714285714 & -0.01045296167 \\
2018 & 0.6341463415 & 0.5977443609 & 0.03640198056 \\
2019 & 0.6341463415 & 0.5206766917 & 0.1134696497 \\
2020 & 0.5909090909 & 0.5 & 0.09090909091 \\
\hline
\end{tabular}

From the table, the study finds that $\bar{d}=0.04860016852$ and $s_{d}=0.03813895447$. $\mathrm{n}=19$.

$$
\begin{aligned}
& t=\frac{\bar{d}}{\frac{s_{d}}{\sqrt{n}}}=\frac{0.04860016852}{\frac{0.038313859447}{\sqrt{19}}}=5.55579 \\
& \text { d.f. }=\mathrm{n}-1=19-1=18
\end{aligned}
$$


The P-value falls to the right of 3.922 from the "Critical Values for Student's t distribution." $3.922<\mathrm{P}-$ Value for the sample $\mathrm{t}$.

Since the interval containing the P-Value of sample t lies to the right of $\alpha=0.01$, we reject $H_{0}$.

At the $1 \%$ level of significance and even the $0.1 \%$ level of significance, we conclude that the Cold Weather Team Games at Home During December, January have an advantage over All Home Games which includes the 2020 season.

3.4. Test 4:Cold Weather Teams Games at Home During December, January, and February, and All Home Games (without the 2020 NFL Season).

$H_{0}: \mu_{d}=0, H_{1}: \mu_{d}>0, \alpha=0.01$

The study begins by pairing the seasons together as a pair. For instance, 2002 Cold Weather Team Winning Percentage with All Team Home Games Winning Percentage which leaves the following table.

Table 6: Paired Differences Table for Test 4.

\begin{tabular}{|l||l||l|l|}
\hline \multicolumn{5}{|c|}{ Paired Differences Table } \\
\hline \multicolumn{5}{|c|}{ Weason } & Cold Team Games at & D=B-A \\
Team Games at & Home (A) & \\
Home During De- & & \\
cember, January, & & \\
\hline 2002 & and February (B) & & \\
2003 & 0.6829268293 & 0.5883458647 & 0.09458096461 \\
2004 & 0.7105263158 & 0.6127819549 & 0.0977443609 \\
2005 & 0.625 & 0.5676691729 & 0.05733082707 \\
2006 & 0.6363636364 & 0.5827067669 & 0.05365686945 \\
2007 & 0.575 & 0.5413533835 & 0.03364661654 \\
2008 & 0.6315789474 & 0.5714285714 & 0.06015037594 \\
2009 & 0.6129032258 & 0.5695488722 & 0.04335435363 \\
2010 & 0.5526315789 & 0.5751879699 & -0.02255639098 \\
2011 & 0.5909090909 & 0.5526315789 & 0.03827751196 \\
2012 & 0.619047619 & 0.5751879699 & 0.04385964912 \\
2013 & 0.5853658537 & 0.5733082707 & 0.01205758298 \\
2014 & 0.6097560976 & 0.5996240602 & 0.01013203741 \\
2015 & 0.6216216216 & 0.5770676692 & 0.04455395245 \\
2016 & 0.5652173913 & 0.5413533835 & 0.02386400785 \\
2017 & 0.6888888889 & 0.5864661654 & 0.1024227235 \\
2018 & 0.5609756098 & 0.5714285714 & -0.01045296167 \\
2019 & 0.6341463415 & 0.5977443609 & 0.03640198056 \\
\hline
\end{tabular}

From the table, the study finds that $\bar{d}=0.04624967283$ and $s_{d}=0.03780207387$. $\mathrm{n}=18$.

$$
\begin{aligned}
& t=\frac{\bar{d}}{\frac{s_{d}}{\sqrt{n}}}=\frac{0.04624967283}{0.03780207387}=5.18993 \\
& \text { d.f. }=\mathrm{n}-1=18-1=17
\end{aligned}
$$

The P-value falls to the right of 3.965 from the "Critical Values for Student's t distribution." $3.965<$ P-Value for the sample t. 
Since the interval containing the P-Value of sample t lies to the right of $\alpha=0.01$, we reject $H_{0}$.

At the $1 \%$ level of significance and even the $0.1 \%$ level of significance, we conclude that the Cold Weather Team Games at Home During December, January have an advantage over All Home Games which does not include the 2020 season.

\section{Discussion}

These results mean that although prior studies conclusions have shown that the impact of home-field advantage decreases year over year, it has been shown that NFL teams playing in an outdoor environment (not a dome) above the $39^{\circ} \mathrm{N}$ latitude line have a statistically significant advantage over teams whose home stadiums is below the the $39^{\circ} \mathrm{N}$ latitude line or play in a controlled playing environment (a dome) $[62,63]$. The results suggest that Cold Weather Teams have been more successful on average at home than non cold weather teams. This would imply these teams win more division titles, Wild Card Round games, Divisional Round games, Conference Championships, and participate in more Super Bowls. As for this data, of the 19 years studied, 15 of 19 of the years included Cold Weather Teams winning the Super Bowl or World Championship Game of the NFL (New England Patriots with 5 Super Bowls in 2003, 2004, 2014, 2016, and 2018 seasons, New York Giants with 2 Super Bowls in 2007 and 2011 seasons, Pittsburgh Steelers with 2 Super Bowls in 2005 and 2008, and 6 teams with 1 Super Bowl title), 10 of 19 Super Bowl Runner Ups, 28 of 38 American Football Conference (AFC) Championship Game teams, and 17 of 38 National Football Conference (NFC) Championship Game Teams. These results matter because this could change how betting services such as DraftKings and FanDuel set the lines for games in December, January, and February. These results could also be used so that the average fan could understand how much weather and more specifically colder weather and snow plays a factor in the outcome of a game. The data gathered is very reliable as it is winning percentages that are based off of NFL data. The potential mistake comes as there are a different amount of cold weather games every year which could cause varying differences in the means. Other reasons for limitations on results are that Colder Weather Teams have been very successful which could have skewed the results as playoff games are held at the stadium of the higher seeded team and these teams were successful during December, January, and February to reach these points. The limitation to only 19 years also affects the results and this data could be expanded to the entire Super Bowl era of the NFL beginning in 1967 for a larger sample size of results. More research could go into what types of weather have a larger impact on games or try to determine the full causes of weather on playing capacity of NFL players.

\section{Conclusion}

By the results of this article, the research project rejected the null hypothesis and left no doubt that Cold Weather Teams have a mathematically significant advantage over all other NFL teams during December, January, and February and in comparison to all other times of the year. However, the NFL is constantly changing to bigger and better stadiums with teams shifting to more indoor environments for playing games. For that reason, these results may be ever changing and with players

such as Tom Brady who has played through the duration of this study with mainly 
the New England Patriots and contributed to 5 Super Bowls during this period, the ebb and flow of the NFL success was not able to be adequately seen. Yet, the NFL's Cold Weather Teams thrived in late season games and provided for lots of success which resulted in the conclusion of a statistical advantage for them. 2020 was the perfect year for weather to play the biggest factor as many teams had the second biggest $d$ value because fans and their impact was in a sense controlled. Since 2020 had a big d value and all of the paired differences tests rejected the null hypothesis, this research project ultimately concluded that Cold Weather Teams during December, January, and February have a statistically significant advantage over other teams.

Acknowledgements. I would like the thank the 5th International Conference of Mathematical Sciences (ICMS 2021) for the opportunity to publish and present these findings. I would like to thank Mehmet Dik for providing me this opportunity to do this research. The late Ranjan Roy for pushing me to pursue mathematics further and the Green Bay Packers and Packers Pro Shop for allowing me to do this research.

\section{REFERENCES}

[1] Tom Pelissero, Ian Rapoport. NFL Plans to Expand Regular Season to 17 Games per Team in 2021, NFL, 27 Dec. 2020, www.nfl.com/news/ nfl-plans-to-expand-regular-season-to-17-games-per-team-in-2021\#: : text=There\% 20 still $\% 20$ would $\% 20$ be $\% 20$ one, games $\% 20$ to $\% 20$ each $\% 20$ team's $\% 20$ schedule

[2] Heyen, Billy. "How Many Teams Make the NFL Playoffs? Updated Standings for 2021 Expanded Playoff Bracket." Sporting News, (Getty Images/SN Illustration), 4 Jan. 2021, www.sportingnews.com/us/nfl/news/nfl-playoffs-2021-teams-standings/ zhx0cwwzh5p61j4y3pxab1lkn\# : : text=The\%202020\%20NFL\%20playoffs $\% 20$ will, to\% 20 the\% 20 four\%20division\%20winners

[3] Breech, John. "NFL Makes Major Changes to 2020 Schedule: Here Are the Winners and Losers of the League's Reshuffling.", CBS, 12 Oct. 2020, www.cbssports.com/nfl/news/ nfl-makes-major-changes-to-2020-schedule-here-are-the-winners-and-losers-of- $\backslash$ the-leagues-reshuffling/

[4] Orr, Conor. "The Broncos' Quarterback-Less Game Was More Sad Than Amusing." Sports Illustrated, 30 Nov. 2020, www.si.com/nfl/2020/11/30/ denver-broncos-sad-quarterbacks-covid

[5] Schultz , Kyley. "VERIFY: Has a Team Ever Played a Super Bowl Game at Their Home Stadium Before?", WUSA 9, 4 Feb. 2021, www.wusa9.com/article/news/verify/ has-tampa-bay-ever-won-a-superbowl-what-time-is-the-superbowl-first-team-to-play- 1 superbowl-at-home-stadium-fact-check-when-is-the-superbowl/ 65-be0c8d39-5f83-4c99-bf85-6b21f902dcd2

[6] "Soldier Field, IL. Soldier Field, Illinois Latitude/Longitude, www.lat-long.com/ Latitude-Longitude-418694-Illinois-Soldier_Field.html

[7] "GPS Coordinates (Latitude and Longitude) of Memorial Stadium, Champaign, IL, USA. Get Directions, www.get-direction.com/address-to-lat-long.html?place= Memorial+Stadium $\% 2 \mathrm{C}+$ Champaign $\% 2 \mathrm{C}+\mathrm{IL} \% 2 \mathrm{C}+\mathrm{USA}$

[8] "Lambeau Field. GeoHack, geohack.toolforge.org/geohack.php?pagename=Lambeau_ Fieldms=44_30_5_N_88_3_44_W_type\%3Alandmark_scale\%3A2000

[9] "Arrowhead Stadium." GeoHack, geohack.toolforge.org/geohack.php?pagename= Arrowhead_Stadiumms=39_2_56_N_94_29_2_W_type\%3Alandmark_scale\%3A200

[10] "Bills Stadium." GeoHack, geohack.toolforge.org/geohack.php?pagename=Bills_ Stadiumms=42.774_N_78.787_W_type\%3Alandmark_scale\%3A2000

[11] "Bills Toronto Series." American Football Database, americanfootballdatabase.fandom. com/wiki/Bills_Toronto_Series 
[12] "Rogers Centre, Canada." GPS Coordinates Address of Rogers Centre, Ontario Canada, Travel to Rogers Centre, All Top Sights, www.alltopsights.com/ attraction-rogers-centre-ontario/.

[13] "FirstEnergy Stadium." GeoHack, geohack.toolforge.org/geohack.php?pagename= FirstEnergy_Stadiumms=41_30_22_N_81_41_58_W_region\%3AUS_type\%3Alandmark .

[14] "Paul Brown Stadium." GeoHack, geohack.toolforge.org/geohack.php?pagename=Paul_ Brown_Stadiumms=39.095_N_84.516_W_type\%3Alandmark_scale\%3A2000.

[15] "GPS Coordinates for Empower Field at Mile High." GPS Coordinates for Empower Field at Mile High. CoordinatesFinder.com, ww..coordinatesfinder.com/coordinates/ 608596-empower-field-at-mile-high.

[16] "Gillette Stadium." GeoHack, geohack.toolforge.org/geohack.php?pagename=Gillette_ Stadiumms=42.091_N_71.264_W_type\%3Alandmark_scale\%3A2000.

[17] "Heinz Field." GeoHack, geohack.toolforge.org/geohack.php?pagename=Heinz_Fieldms= 40_26_48_N_80_0_57_W_type\%3Alandmark_scale\%3A2000.

[18] "Veterans Stadium." GeoHack, geohack.toolforge.org/geohack.php?pagename=Veterans_ Stadiumms=39_54_24_N_75_10_16_W_type\%3Alandmark_globe\%3Aearth_region\%3AUS-PA .

[19] "Lincoln Financial Field." GeoHack, geohack.toolforge.org/geohack.php?pagename= Lincoln_Financial_Fieldms=39_54_3_N_75_10_3_W_type\%3Alandmark_scale\%3A2000_ region\%3AUS .

[20] "Lumen Field." GeoHack, geohack.toolforge.org/geohack.php?pagename=Lumen_ Fieldms=47.5952_N_122.3316_W_type\%3Alandmark_scale\%3A5000.

[21] "M\&T Bank Stadium." GeoHack, geohack.toolforge.org/geohack.php?pagename=M\%26T_ Bank_Stadiumms=39_16_41_N_76_37_22_W_type\%3Alandmark_region\%3AUS-MD .

[22] "Giants Stadium." GeoHack, geohack.toolforge.org/geohack.php?pagename=Giants_ Stadiumms=40_48_44_N_74_4_37_W_type\%3Alandmark_scale\%3A2000.

[23] "MetLife Stadium." GeoHack, geohack.toolforge.org/geohack.php?pagename=MetLife_ Stadiumms=40_48_48.7_N_74_4_27.7_W_type\%3Alandmark_scale\%3A2000.

[24] "TCF Bank Stadium." GeoHack, geohack.toolforge.org/geohack.php?pagename=TCF_ Bank_Stadiumms=44.976_N_93.225_W_type\%3Alandmark_region\%3AUS-MN .

[25] McClain, John. "How the Oilers Left Houston and Set the Stage for the Texans." Houston Chronicle, 19 Aug. 2016, www.chron.com/local/history/sports/article/ How-the-Oilers-left-Houston-and-set-the-stage-for-9171976.php.

[26] Wackerly, Dennis D., et al. Mathematical Statistics with Applications. 7th ed., Brooks/Cole, 2012.

[27] "NFL Standings." ESPN, www.espn.com/nfl/standings.

[28] "Official Website of the Atlanta Falcons Football Club." Falcons Schedule - Atlanta Falcons - Atlantafalcons.com, www.atlantafalcons.com/schedule/.

[29] "The Official Site of the Arizona Cardinals." Cardinals Schedule I Arizona Cardinals AZCardinals.com, www. azcardinals.com/schedule/.

[30] "Ravens." Ravens Schedule - Baltimore Ravens - Baltimoreravens.com, www. baltimoreravens.com/schedule/.

[31] "The Official Website of the Buffalo Bills." Buffalo Bills Schedule - Buffalo Bills, www. buffalobills.com/schedule/.

[32] "Carolina Panthers Schedule." www.panthers.com/schedule/.

[33] "Cincinnati Bengals Schedule" The Official Site of the Cincinnati Bengals, www.bengals. com/schedule/.

[34] "Schedule: The Official Website of the Chicago Bears." The Official Website of the Chicago Bears, www. chicagobears. com/schedule/.

[35] "Cleveland Browns." Browns Home, www.clevelandbrowns.com/schedule/.

[36] "Official Site of the Dallas Cowboys." Dallas Cowboys, www.dallascowboys. com/schedule/.

[37] "Denver Broncos Schedule." Denver Broncos, www.denverbroncos.com/schedule/.

[38] "The Official Site of the Detroit Lions." Detroit Lions Schedule - Detroit Lions - DetroitLions.com, www.detroitlions.com/schedule/.

[39] "Official Site of the Houston Texans." Texans Home, www.houstontexans.com/schedule/.

[40] "Packers.com, the Official Website of the Green Bay Packers." Packers Schedule - Green Bay Packers - Packers.com, www.packers.com/schedule/.

[41] "The Official Website of the Indianapolis Colts." Colts Schedule- Indianapolis Colts, www. colts.com/schedule/. 
[42] “2021 Jacksonville Jaguars Schedule." Jacksonville Jaguars Schedule, www.jaguars.com/ schedule/.

[43] "Official Website of the Kansas City Chiefs." Kansas City Chiefs, www.chiefs.com/ schedule/.

[44] "2020 Schedule: Las Vegas Raiders." Las Vegas Raiders, www.raiders.com/schedule/.

[45] "Los Angeles Chargers." Chargers Schedule - Los Angeles Chargers, www.chargers.com/ schedule/.

[46] "Official Site of the Los Angeles Rams." Rams Schedule - Los Angeles Rams, www.therams. com/schedule/.

[47] "Miami Dolphins." Dolphins.com, www.miamidolphins.com/schedule/.

[48] "The Official Site of the Minnesota Vikings." Minnesota Vikings - Vikings.com, www. vikings.com/schedule/.

[49] "New England Patriots." Official Website of the New England Patriots, www.patriots.com/ schedule/.

[50] "New York Football Giants." Giants Schedule - New York Giants - Giants.com, www. giants.com/schedule/.

[51] "Official Site of the New York Jets." New York Jets - Schedule, www.newyorkjets.com/ schedule/.

[52] "Philadelphia Eagles." Philadelphia Eagles Schedule, www.philadelphiaeagles.com/ schedule/.

[53] Organization, and ImageObject. "NFL Flex Scheduling Verbiage." Steelers Schedule Pittsburgh Steelers - Steelers.com, 18 Apr. 2019, www.steelers.com/schedule/.

[54] "San Francisco 49ers." 49ers Schedule - San Francisco 49ers, www.49ers.com/schedule/.

[55] "Seattle Seahawks." Seahawks Schedule - Seattle Seahawks - Seahawks.com, www.seahawks. com/schedule/.

[56] "Tampa Bay Buccaneers." Buccaneers Schedule - Tampa Bay Buccaneers - Buccaneers.com, wWw. buccaneers.com/schedule/.

[57] "The Official Site of the Tennessee Titans." Titans Home, ww.tennesseetitans.com/ schedule/.

[58] "Schedule." Schedule - Washington Football Team - WashingtonFootball.com, www. washingtonfootball.com/schedule/.

[59] "Saints Schedule: New Orleans Saints." Saints Schedule-New Orleans Saints NewOrleansSaints.com, www.neworleanssaints.com/schedule/

[60] Brase, Charles Henry, and Corrinne Pellillo Brase. Understanding Statistics. 9th ed., Houghton Mifflin Harcourt, 2009.

[61] Borghesi, Richard. "The Home Team Weather Advantage and Biases in the NFL Betting Market." Journal of Economics and Business, vol. 59, 11 Sept. 2006, pp. 340-354., doi:https://hughchristensen.com/papers/academic_papers/borghesi2007.pdf.

[62] Owen, Ben. "How Important Is Home-Field Advantage in the NFL?" Sports Articles, 5 Apr. 2021, ww.lineups.com/articles/ how-important-is-home-field-advantage-in-the-nfl/.

[63] Sharp, Warren. "NFL Home-Field Advantage: It's Not As Important As It Once Was: Sharp Football." Sharp Football Analysis, Sharp Football Analysis, 15 Aug. 2019, www. sharpfootballanalysis.com/analysis/nfl-home-field-advantage/.

[64] NFL Throwback, director. Evolution of Every NFL Team's EVERY Stadium - NFL Explained. Performance by Jon Kendle, YouTube, 14 Oct. 2020, www.youtube.com/watch?v= sWSO4BxJkVk.

BRANDON JOLY,

700 College Street Beloit College Box 693, Beloit, Wisconsin, USA 53511, Phone: (920)639-3849

Email address: jolybs@beloit.edu

Mehmet Dik,

700 College Street, Beloit, Wisconsin, USA 53511, Phone: (815)226-4135

Email address: mdik@rockford.edu 